\title{
PAX5 NM_016734.2:C.547G>A
}

National Cancer Institute

\section{Source}

National Cancer Institute. PAX5 NM 016734.2:C.547G>A. NCI Thesaurus. Code C158143.

A nucleotide substitution at position 547 of the coding sequence of the PAX5 gene where guanine has been mutated to adenine. 